\title{
Syariat Islam Tentang Relasi \\ Dan Toleransi Antar Umat Beragama Dalam Al-Qur'an
}

\author{
Yusefri \\ Sekolah Tinggi Agama Islam Negeri (STAIN) Curup \\ E-mail:yusefri_ys@yahoo.com
}

\begin{abstract}
Abstrak
Tulisan ini pada intinya melakukan kajian tentang bagaimana ketentuan syariat Islam yang mengatur hubungan antara seorang muslim dengan non muslim dalam rangka mewujudkan kerukunan antar umat beragama. Kajian ini dilakukan karena yang ada sejak zaman klasik, kitab-kitab fikih, yang merupakan kumpulan hasil pemikiran ulama tentang formulasi syaria (hukum) Islam yang digali dari sumbernya, terlihat belum banyak memuat bahasan tentang ketentuan yang berhubungan perbuatan seorang muslim dengan non muslim. Objek kajian lebih difokuskan pada ayat-ayat alQur`an yang berhubungan dengan persoalan ini. Dengan menggunakan pendekatan analisis tafsir, ternyata terbukti bahwa syariat Islam telah meletakkan ketententuan-ketentuan yang jelas mengatur hubungan antara seorang muslim dengan non muslim, diantaranya mengaharuskan berperilaku toleran, tidak boleh memaksa dan anarkis.
\end{abstract}

Kata Kunci: Agama, dan Kerukunan

\begin{abstract}
This paper essentially conducted a study on how the provisions of Islamic law that governs the relationship between a Muslim with non-Muslims in order to realize inter-religious harmony. The study was conducted because since the classical times, there were books of fiqh, which is a collection of the scholar's ideas about the formulation of Islamic syaria (law) extracted from the source, had not seen yet containing the discussion about many provisions related to the deed of a Muslim with non-Muslims. The object of study is more focused on the verses of alQuran related to this issue. By using the analytical approach of interpretation, proved that Islamic law has laid clear provisions regulating the relationship between a Muslim and non-Muslims, including compelled to behave tolerant, should not enforcing and anarchists.
\end{abstract}

Keywords: Religion, and Harmony

Al Istinbath : Jurnal Hukum Islam vol. 2, no. 1, 2017

STAIN Curup-Bengkulu | p-issn: 2548-3374; e-issn: 2548-3382

Available online at : http://journal.staincurup.ac.id/index.php/alistinbath 


\section{A. Pendahuluan}

Dalam konteks ke-Indonesiaan khususnya, persoalan agama dan kehidupan keagamaan sudah menjadi bagian yang tak terpisahkan dari kehidupan berbangsa dan bernegara. Indonesia, secara realitas diakui bahwa sebagai negara yang memiliki keragaman suku, budaya dan agama. Di satu sisi keragaman itu merupakan suatu kekayaan, namun di sisi lain menyimpan potensi terjadi konflik suku ras dan agama (SARA). Menyadari akan realitas inilah maka sejak proses pembentukan Negara Kesatuan Republik Indonesia (NKRI), persoalan agama dan kehidupan beragama mendapat perhatian serius dari para father founder bangsa ini. ${ }^{1}$ Indikasi dari keseriusan ini antara lain dapat dilihat dari sejumlah kebijakan negara (pemerintah) yang tertuang dalam undang-undang dan Peraturan yang mengatur kehidupan beragama yang dimaksudkan untuk terciptanya kerukunan hidup bergama. Sejumlah kebijakan, undang-undang dan peraturan menyangkut penataan dan pengaturan kehidupan beragama antara lain sebagai berikut.

a) UUD 1945 pasal 29 ayat 2 menyebut; "Negara menjamin kemerdekaan tiaptiap penduduk untuk memeluk agamanya masing-masing dan untuk beribadat menurut agamanya dan kepercayaannya itu;" 2

b) Departemen Agama RI dibentuk tanggal 3 Januari 1946 yang bertugas menangani agama dan kehidupan keagamaan ${ }^{3}$;

c) Penetapan Presiden RI Nomor 1 tahun 1965 tentang Pencegahan dan Penyalah-gunaan dan/atau penodaan Agama;

d) Keputusan Bersama Menteri Agama dan Menteri dalam Negeri Nomor 01/BER/Mdn-Mag/1969 tentang Pelaksanaan Tugas Aparatur Pemerintahan dalam menjamin Ketertiban dan Kelancaran Pelaksanaan Pengembangan dan Ibadat Agama oleh Pemeluk-pemeluknya;

\footnotetext{
${ }^{1}$ Departeman Agama RI, Pedoman Dasar Kerukunan Hidup Beragama, Proyek Pembinaan Kerukunan Hidup Beragama, 1979, h. 9-10.

${ }^{2}$ Kalimat " negara menjamin" yang terdapat pada pasal 29 ayat 2, bukan menjamin kemerdekaan dalam arti pasif, tetapi jelas bersifat aktif dan imperatif. Keaktifan negara dalam menjamin kemerdekaan memeluk agama mempunyai dua aspek. Pertama, negara berkewajiban bertindak sebagai fasilitator bagi terselenggaranya peribadatan oleh kalangan peme-luk agama, sepanjang hal itu diperlukan oleh para pemeluknya, tanpa negara mencampuri otoritas dan otonomi ajaran agama. Kedua, negara berkewajiban untuk mencegah terjadinya gangguan yang datang dari luar lingkungan suatu agama dari manapun datangnya.

${ }^{3}$ Ada 12 tugas dan fungsi pokok utama Departemen Agama. Salah satunya adalah: meningkatkan usaha untuk tetap terpeliharanya suasana kerukunan hidup beragama sebagai salah satu syarat untuk lebih memantapkan stabilitas dan ketahanan Nasional yang sangat diperlukan untuk mensukseskan pembangunan Nasional di segala bidang. Departemen Agama RI, Pedoman Dasar Kerukunan Hidup Beragama, Jakarta: Proyek Pembinaan Kerukunan Hidup Beragama Depag RI, 1979, h. 8-9
} 
e) Keputusan Menteri Agama Nomor 35 Tahun 1980 tentang Wadah Musyawarah Antar Umat Beragama;

f) Intruksi Menteri Agama RI Nomor 3 tahun 1981 tentang pelaksanaan Pembinaan Kerukunan Beragama, dan;

g) Keputusan Menteri Agama RI Nomor 84 tentang penanggulangan kerawanan Kerukunan Hidup beragama. ${ }^{4}$

Meski demikian pada kenyataannya, menurut Dadang Kahmad, ${ }^{5}$ untuk mewujudkan kerukunan hidup dalam hubungan antar umat beragama tidak mudah dilaksanakan sebagaimana dalam dataran konsep dan aturan. Ada banyak faktor determinan yang mungkin menjadi penghambat terjadinya kerukunan, atau mungkin pula di dalam penelitian dapat ditemukan faktor pendorong utama terjadinya konflik diantara pemeluk agama tersebut. Antara lain faktor tersebut adalah agama sebagai sebuah institusi keyakinan subjektif, tidak jarang mendorong pemeluknya untuk mempunyai perasaan etnosentrisme, yaitu perasaan bahwa agama yang dipeluknya itu adalah yang paling benar. Karena sifat subjektif itu pula, masyarakat beragama cenderung menganggap agama orang lain salah dan sesat (ekslusifisme). Kecenderungan ekslusifitas ini dalam perspektif psikologis dan sosiologis agama, sebuah fenomena yang dimiliki hampir di seluruh agama. ${ }^{6}$

Doktrin tentang eksklusivitas agama; -"bahwa agama sayalah yang paling benar, agama lain sesat dan menyesatkan.", dalam sejarah kelihatannya telah lama berkembang. Pandangan semacam ini sangat kental, bahkan sampai sekarang, seperti termuat dalam tidak hanya buku-buku polemis, tetapi juga buku ilmiah. Rumusan dari Ajith Fernando, teolog kontemporer misalnya menyatakan : “ Other religions are false path that mislead their followers" (agama lain adalah jalan sesat dan menyesatkan pengikutnya). ${ }^{7}$ Ungkapan Ajith Fernando ini jelas sangat fulgar, langsung tergambar segi eksklusivitasanya bahkan terkesan "provokatif". Karena bagaimanapun pernyataan Ajith itu, bisa menyinggung emosi (rasa) pemeluk agama lain dan mengusik keharmonisan kerukunan hidup bergama yang pada giliriannya dapat menyulut terjadinya konflik sosial. ${ }^{8}$ Demikian pula

${ }^{4}$ Kebijakan Negara RI dalam bentuk undang-undang dan keputusan pemerintah di atas dapat dilihat pada: Badan Litbang Agama dan Diklat Keagamaan, Kompilasi Peraturan PerundangUndangan Kerukunan Hidup Umat Beragama, Jakarta: Depatemen Agama RI, 2003, h. xvi - xviii

${ }^{5}$ Dadang Kahmad, Metode Penelitian Agama, Bandung: Pustaka Setia, 2000, h. 76.

${ }^{6}$ TB. Sumarna, Dialog, Kritik, Identitas Agama, Yogyakarta: Dian Interfide, 2002, h. 131

${ }^{7}$ Budhy Munawar Rachman, Mengembalikan Kerukunan Umat Beragama, dalam Majalah Ihklas Beramal Departemen Agama, Nomor 47 Tahun X 2007, h. 45.

${ }^{8}$ Meski berbagai analisis menunjukkan bahwa faktor sosial, politik dan ekonomi cukup mewarnai terjadinya konflik tersebut, tapi faktor agama tidak bisa ditampik perannya dalam konfik sosial. Fenomena sentimen keagamaan yang berujung pada terjadinya konfik horizontal antar pemeluk agama yang berbeda ini, bahkan tidak hanya ada di Indonesia, tapi juga di 
yang baru terjadi. Gubernur DKI , Basuki Cahaya Purnama, alias Ahok, yang kini telah ditetapkan sebagai tersangka karena pernyataannya yang dianggap menistakan agama, nampak jelas menimbulkan tekersinggungan umat Islam dan nyaris menyulut terjadinya konfik.

Dalam dunia Islam, fenomena ekslusifisme dalam bergama ini, setidaknya dalam konteks kikinian, terlihat beberapa kejadian "bom bunuh diri" yang mengatas namakan agama (jihad). Hingga di sini muncul pertanyaan, apakah dalam syariat Islam ada mengandung ajaran ekslusifisme dalam beragama ? Bagaimana al-Qur'an sebagai sumber pokok syariat Islam melihat agama, dan bagaimanakah ketentuan-ketentuan yang ditetapkan syariat Islam dalam kaitannya dengan agama lain? Beberapa pertanyaan ini aktual dan menarik dibicarakan karena Islam, oleh paling tidak oleh pengikutnya, diklaim sebagai agama yang rạmatan lil 'âlamîn.

\section{B. Pembahasan}

\section{Agama Menurut al-Qur`an}

Dalam al-Qur`an, setidaknya ada dua istilah yang makna berarti agama, yaitu al-dîn dan millah. Namun istilah yang lazim digunakan untuk menyebut

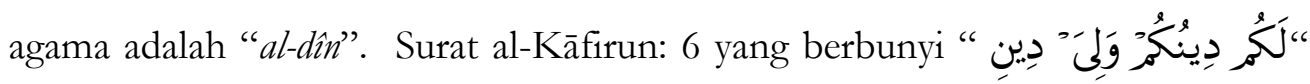
biasanya diterjemahkan dengan "bagimu agamamu dan bagiku agamaku."

Secara bahasa kata al-dîn adalah bentuk mashdar (kata benda jadian) dari akar kata "dana - yadînu”. Dalam bahasa Arab, kata dasar yang asalnya terdiri dari huruf "dal, ya dan nun" memiliki banyak arti antara lain: memberi pinjaman atau berhutang, taat, menundukkan, merendahkan, melayani, membalas, memiliki, hisab atau perhitungan, kekuasaan, pengaturan, paksaan, kemenangan, keputusan, aturan, undang-undang, agama, adat, kebiasaan dan perkara urusan. ${ }^{10}$ Apabila makna makna yang terkandung dari akar kata “dana - yadînu”, maka istilah al-dîn berarti undang-undang atau peraturan penguasa alam semesta untuk

belahan bumi luar Indonesia misalnya, di India antara kaum Sikh, Hindu dan Islam; di negara bekas Yugoslavia antara Muslim Bosnia dengan Kristen Serbia; di Filiphina antara kelompok Islam Moro dengan kelompok Kristen, serta kerusuhan kerusuhan di Lebanon dll. Khusus di Indonedia beberapa kasus kerusuhan bernuansa sentimen keagaaman cukup serius yang terjadi dalam tahun-tahun belakangan ini antara lain adalah kerusuhan di Poso Sulawasi Tengah, kasus Maluku, tragedi Satu tujuh Satu di Nusa Tenggara Barat, dan lain sebagainya. Demikian pula kasus pembakaran rumah ibadah agama Kristen (Gereja) yang terjadi di beberapa tempat barubaru ini.

${ }_{9}$ Departemen Agama RI, Al-Qur an dan Terjemabnya, Semarang: Toha Putra, 1996, h. 484

${ }^{10}$ Luwis Ma luf, Al-Munjid fi al-Lughah, Beirût: Dâr al-Masyriq, 1986, h. 231. Juga, Ahmad Warson Munawwir, Kamus al-Munawwar, Yogyakarta: Pustaka Progresif, 1997, 437 
digunakan sebagai pedoman hidup, harus ditaati, dipatuhi dan akan dimintai pertanggung jawaban atas pelaksanaannya; kebaikan dibalas baik, keburukan dibalas buruk pula. Dengan demikian istilah al-din mencakup makna segala aspek penguasa alam semesta, kehidupan mulai dari aspek sosial, ekonomi, budaya, pendidikan, politik, hukum dan lain-lain menyangkut masalah duniawi dan ukhrawi. ${ }^{11}$

Dalam al-Qur`an, kata al-dinn, baik yang disebut secara sendiri maupun digandengkan dengan kata lain, diulang sebanyak $91 \mathrm{kali}^{12}$ dan dapat dirinci dalam tabel berikut.

Tabel

Bentuk-bentuk kata “al-din” yang disebut dalam al-Qur`an

\begin{tabular}{|c|c|c|}
\hline No & Uraian bentuk kata "al-dîn" & Jumlah \\
\hline 1 & Dalam bentuk berdiri sendiri “al-dîn" (al-dìnu, al-dîni, al-dinna) & 53 \\
\hline 2 & $\begin{array}{l}\text { Bergandengan dhamir (kata ganti) jamak mukhâthabah "kum" = } \\
\text { "dînukum" }\end{array}$ & 11 \\
\hline 3 & $\begin{array}{l}\text { Bergandengan dhamîr (kata ganti) orang ketiga tunggal (mufrad al- } \\
\text { ghaib) "buwa" = "dinihi" }\end{array}$ & 2 \\
\hline 4 & $\begin{array}{l}\text { Bergandengan dhamîr (kata ganti) orang ketiga banyak (jamak al- } \\
\text { ghaib) "bum" = "dînibim/dînubum" }\end{array}$ & 10 \\
\hline 5 & $\begin{array}{l}\text { Bergandengan dhamîr (kata ganti) orang pertama tunggal (mufrad } \\
\text { al-mutakallim) "diniy" }\end{array}$ & 2 \\
\hline 6 & Bergandengan dengan kata "yaum" (hari) "yaum al-dîn" & 13 \\
\hline & Jumlah & 91 \\
\hline
\end{tabular}

Dalam terjemahan yang lazim, kata al-dîn yang digunakan dalam al-Qur’an menunjuk kepada banyak arti. Namun makna al-din yang paling menonjol dalam al-Qur'an ada lima makna. Pertama, al-dîn berarti pembalasan atau balas jasa; terutama jika kata al-din digandengkan dengan kata yaum. Misalnya, Q.S alFâtihah (1) : 3; al-Dzâriyat (51) : 6; al-Infithâr (82): 17.

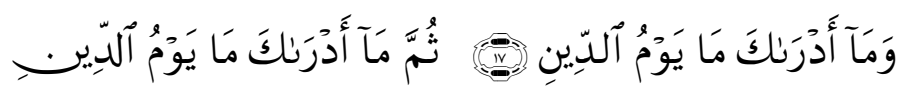

"Tabukah kamu Apakah hari pembalasan itu? Sekali lagi, tabukah kamu Apakah hari pembalasan itu? (Q.S al-Infithâr/82: 17) ${ }^{13}$

\footnotetext{
11 Abdurrahman Madjrie, Meluruskan Aqidah, Jakarta, Khairul Bayan, 2003, h. 14-15

${ }^{12}$ Muhammad Fu'ad 'Abd al-Baqiy, selanjutnya ditulis 'Abd al-Baqiy, Al-Mu'jam al-Mufahras

Lialfazh al-Qur'an al-Karim, Surabaya, Maktabah Dahlan, tth. 340-342

${ }^{13}$ Departemen Agama RI, Al-Qur'an dan Terjemabnya, Semarang: Toha Putra, 1998, h. 469
} 
52 | Al Istinbath : Jurnal Hukum Islam, Vol. 2, No. 1, 2017

Kedua, al-dîn berarti penyembahan atau ibadah. Misalnya, Q.S al-A'râf (7) : 29; al-Zumar (39) : 2, dan 3 .

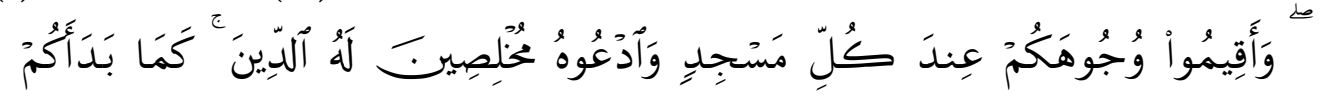

تَعْودُونَ

"'Luruskanlah muka (diri)mu di Setiap sembabyang dan sembablab Allab dengan mengikhlaskan ketaatanmu kepada-Nya. sebagaimana Dia telah menciptakan kamu pada permulaan (demikian pulalab kamu akan kembali kepadaNya)". (Q.S al-A'raf) 7: 29) ${ }^{14}$

Ketiga, al-dîn berarti hukum atau undang-undang negara. Misalnya, Q.S Yusuf (12) : 76 .

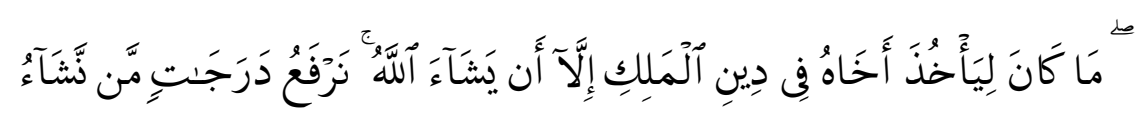

Tiadalah patut Yusuf menghukum saudaranya menurut undang-undang Raja, kecuali Allah menghendaki-Nya. ${ }^{15}$

Keempat, al-dîn berarti agama atau millah. Misalnya, al-An'am (6) : 159; alSyura (42) : 13; al-Kafirun (109) : 6.

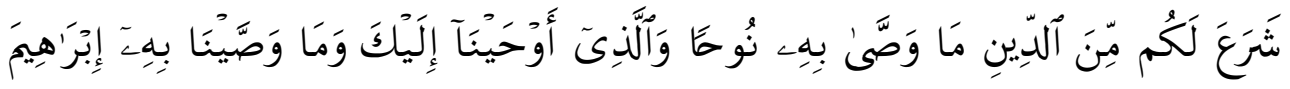

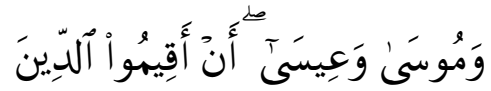

Artinya: Dia telah mensyari'atkan bagi kamu tentang agama apa yang telah diwasiatkanNya kepada Nub dan apa yang telah Kami wabyukan kepadamu dan apa yang telah Kami wasiatkan kepada Ibrabim, Musa dan Isa Yaitu: Tegakekanlah agama (kepada-Nya).(Q.S al-Syura/42: 13) ${ }^{16}$

Kelima, al-din berarti patuh atau taat. Misalnya, Q.S al-Nahl (16) : 52.

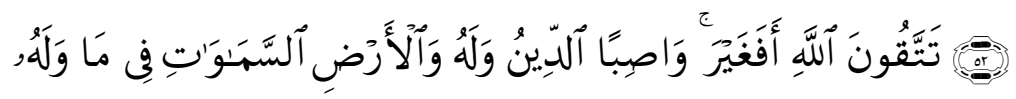

Artinya: dan kepunyaan-Nya-lah segala apa yang ada di langit dan di bumi, dan untukNya-lab ketaatan itu selama-lamanya. Maka mengapa kamu bertakwa kepada selain Allah?(Q.S al-Nahl/16: 52) ${ }^{17}$

\footnotetext{
${ }^{14}$ Ibid., h. 122

${ }^{15}$ Ibid., h. 195

${ }^{16}$ Ibid, h. 386

${ }^{17}$ Ibid., h. 217
} 
Melihat penjelasan ayat-ayat di atas dapat dinyatakan bahwa dalam alQur`an, pengertian agama tidak hanya dibatasi pada gejala hubungan antara manusia dengan Yang Kudus atau Yang Gaib saja. Agama, dalam cakupan Islam, tidak hanya menyangkut hubungan vertikal antara manusia dengan Tuhan, tetapi juga hubungan horizontal antara sesama manusia. ${ }^{18}$

Mengakui adanya Tuhan dan menyembah-Nya adalah merupakan inti dari setiap agama dan kepercayaan. Potensi pengakuan ini sudah dibawa manusia semenjak ia lahir ke dunia, bahkan menurut al-Qur'an (Islam), sebagaimana dikatakan para ahli, sudah menjadi ikrar (ikatan) primordial sebelum manusia terlahir. Hal itu digambarkan dalam al-Qur'an surat al-A'râf (7) : 172.

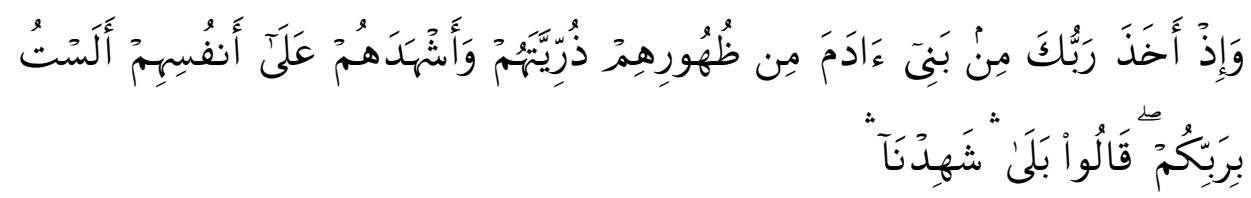

Artinya: "Dan (ingatlab), ketika Tubanmu mengeluarkan keturunan anak-anak Adam dari sulbi mereka dan Allah mengambil kesaksian terbadap jiwa mereka (seraya berfirman): "Bukankah aku ini Tubanmu?" mereka menjawab: "Betul (Engkau Tuban kami), Kami menjadi saksi".."

Ayat di atas, menurut Thabatha'̂̂, sesungguhnya mengingatkan adanya perjanjian (ikatan primordial) antar manusia dengan Tuhan. ${ }^{20}$ Quraish Shihab, dalam Kitab Tafsirnya "al-Misbah", menjelaskan bahwa ayat itu lebih tepat dipahami sebagai islustrasi tentang aneka pembuktian menyangkut keesaan Allah yang melekat pada diri manusia, fitrah dan akal fikiranya. ${ }^{21}$ Ringkasnya, bahwa menurut al-Quran seluruh manusia yang lahir terikat dengan perjanjian primordial itu. Karenanya secara realitas, tidak seorang pun yang tidak mengakui adanya Tuhan, terlepas bagaimana ia mempersepsi tentang Tuhan itu sendiri. Dari hasil para ahli antropologi dan sosiologi, memperlihatkan bahwa suku pedalaman atau primitif seklipun ada ajaran tentang Tuhan yang mereka sembah. Dari sini mereka berkesimpulan bahwa kecenderungan beragama merupakan gejala universal. Manusia tidak bisa menghindar dari ber-Tuhan (beragama). Kebebasannya adalah hanya memilihi antara satu dan lain agama. Masalahnya adalah agama mana yang ia pilih dan anut tergantung persepsi, pengetahuan yang diperolehnya. Dalam kaitan inilah al-Qur an mengingatkan,

\footnotetext{
${ }_{18}$ Dawam Raharjo, Ensiklopedi Al-Qur'an: Tafsir Sosial Berdasarkan Konsep-Konsep Kunci, Jakarta: Temprint, 1996, h. 112

${ }^{19}$ Ibid., h. 137

${ }^{20}$ Muhammad Husain al-Thabatha'i, Al-Mizan fi Tafsir al-Qur'an, Juz VIII, Beirut: Mu`assah al-

'A'lami lil Mathu'at, tth. h. 311

${ }^{21}$ M. Quraish Shihab, Tafsir al-Misbah, Jilid V, Jakarta: Lintera Hati, 2006, h. 305-306
} 
bahwa fitrah ber-Tuhan (beragama) harus ditumbuh kembangkan sesuai dengan fitrahnya." 22

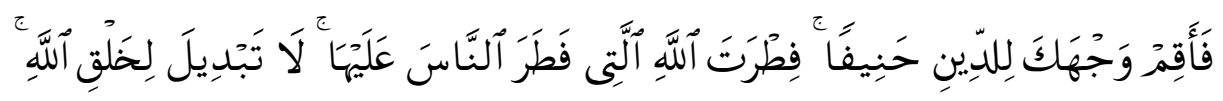

Artinya; "Maka hadapkanlah wajahmu dengan Lurus kepada agama Allab; (tetaplah atas) fitrah Allah yang telah menciptakan manusia menurut fitrah itu. tidak ada peubahan pada fitrah Allah. ${ }^{23}$

2. Jenis Agama Yang Disebut Dalam al-Qur'an

Setidaknya ada tiga agama yang sering disebut dalam al-Qur`an, yaitu Yahudi, Nasrani dan Islam sendiri.

a). Yahudi

Pendiri atau pembawa agama Yahudi adalah Nabi Musa as. Beliau lahir tahun 1570 SM dan wafat tahun 1450 SM. Dalam usia 40 tahun beliau mendapat panggilan dari Tuhan untuk menerima Wahyu. Tugas yang pertama bagi diutusnya Nabi Musa as ialah membebaskan nabi (bangsa) Israil keturunan Nabi Ya'kub as yang pada waktu itu diperbudak oleh bangsa Mesir. ${ }^{24}$

Istilah atau kata Yahudi, dapat merujuk pada dua hal yaitu suku bangsa (bangsa Yahudi) dan sebuah agama (agama Yahudi). Namun keduanya punya hubungan erat yang tak terpisahkan. Sebagai nama suatu bangsa, Yahudi merupakan suku bangsa keturunan Eber "Ibrani”" atau Yakub "Israel". Adapun sebagai nama dari sebuah agama, Yahudi adalah merupakan suatu keyakinan yang dihubungkan dengan ide ketuhanan serta perwujudan suatu bangsa yang telah dipilih Tuhan ${ }^{25}$. Ada juga yang menjelaskan bahwa agama Yahudi itu adalah agama yang dihasilkan oleh proses perkembangan sejarah Bani Israel yang sudah melalui masa sekian lama, ditumbuhkan dari ide Taurat, Talmud dan watak pembawaan bangsa Israel itu sendiri. ${ }^{26}$ Taurat itu sendiri merupakan Kitab Suci yang diturunkan Tuhan (Allah) kepada nabi Musa a.s. Oleh karena itu ia diklaim udah ada sejak adanya nabi Musa, dan diakui sebagai salah satu agama samawi. Dalam bahasa Inggris, orang atau bangsaYahudi disebut Jews dan pemeluknya disebut Judaism.

\footnotetext{
22 Loc. Cit

${ }^{23}$ Departemen Agama Op. Cit, h. 325

24 Abu Ahmadi, Perbandingan Agama, Jakarta: Rineka Cipta, 1991, h. 152.

${ }^{25}$ Romdlon, Agama agama Dunia, Yogyakarta : IAIN SUKA Press : 1988, h. 296

${ }^{26}$ Loc. Cit
} 
Dalam al-Qur`an, kata atau istilah Yahudi (al-Yabûdi/ Yabûdiyyan) yang disebut dengan terulang disebut sebanyak 8 kali. ${ }^{27}$ Diantaranya, Q.S al-Maidah (5): 64

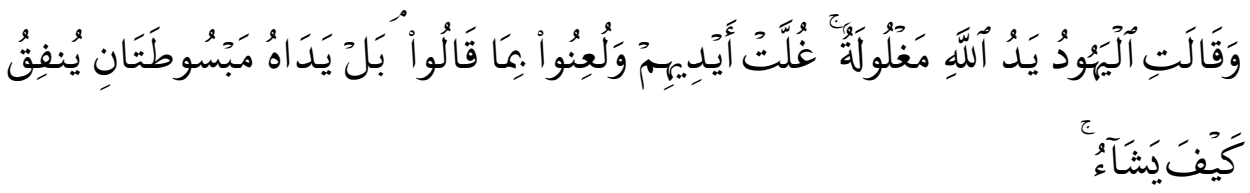

Orang-orang Yahudi berkata: "Tangan Allab terbelenggu sebenarnya tangan merekalah yang dibelenggu dan merekalah yang dilaknat disebabkan apa yang telab mereka katakan itu. (tidak demikian), tetapi kedua-dua tangan Allah terbuka; Dia menafkabkan sebagaimana Dia kehendaki. ${ }^{28}$

b). Nasrani

Istilah Nasrani (bahasa Indonesia) merupakan adopsi dari bahasa Arab "al-Nasbrāñ̄" (bahasa Arab). Al-Zamakhsyarî menyebutkan, kata al-Nashārā adalah bentuk jamak dari kata al-nashränun. Huruf ya' yang terdapat pada kata alNashränî adalah lilmubalagah (bersangatan), seperti halnya yang terdapat pada kata abmarî. Mereka diberi gelar al-Nashärā karena mereka menolong Nabi Isa. ${ }^{29}$ Fakhruddin al-Razi juga berpendapat demikian. Lebih lanjut menurutnya, pengambilan kata al-Nashārā, ada beberapa kemungkinan. Pertama, kampung tempat tinggal Nabi Isa yang bernama al-Nasirah (Nazaret), maka dihubungkan dengan nama Nashärā. Ini adalah pendapat Ibnu Abbas, Qatadah dan Ibnu Juraij. Kedua, karena saling tolong menolong diantara mereka, lalu disebutlah mereka Nashärā. Ketiga, karena adanya perkataan Nabi Isa kepada kaum Hawariyyun : siapakah yang menolongku untuk agama Allah ( من أنصاري إلى اله ), sebab itulah mereka disebut sebagai Nashāra . $^{30}$

Adapun pengertian al-Nashärā yang lain, disebutkan oleh para ulama. Antara lain, yang dimaksudkan dengan al-Nashārā menurut Wahbah Zuhaili adalah para pengikut Nabi Isa. ${ }^{31}$ Sedangkan menurut Nuruddin Adil al-Nashārā adalah nama yang digunakan al-Qur'an terhadap ummat yang mereka yakini Nabi Isa sebagai tuhan atau sebagai anak tuhan, sedikit diantara mereka yang masuk Islam dan meyakini Nabi Isa sebagai Nabi Allah, mereka adalah kaum

\footnotetext{
${ }^{27}$ Muhammad Fuad 'Abd Baqi, Op.Cit, h. 941

${ }^{28}$ Departemen Agama RI, Op. Cit, h.

${ }^{29} \mathrm{Abu}$ al-Qasim Mahmud bin Umar al-Zamakhsyari, al-Kasysyä an Haqāiqi Gawāmidi al-Taṇ̃̂̂l Wa Uyūnu al-Aqāwili fi al-Ta'wîl, Jilid I, Beirût: Dâr al-Kitâab Ilmiah, 1995, h. 148.

${ }^{30}$ Fakhruddun al-Raziy, Tafsir Mafätîh al-Gaib, Jilid I, Beirût: Dar al-Kitab Ilmiah, 2000, h. 536

31 Wahbah Zuhaili, Tafsir al-Munîr, Jikid I, Damsyiq: Daru al-Fikri, 2008, h. 193
} 
Hawariyyun dan nama al-Nashärä ditetapkan sebagai orang Nasrani (Kristen) yang ada pada saat sekarang ini. ${ }^{32}$

Dalam al-Qur`an, kata al-Nashärā disebut sebanyak 14 kali. ${ }^{33}$ Dari 14 kali tersebut, kata al-Nashärā 13 dari padanya dalam berbentuk jama' dan satu dalam berbentuk tunggal. Di dalam semua ayat ini istilah Nashärä diartikan dengan pengikut Nabi Isa a.s. Misalnya, Q.S al-Maidah (5): 82:

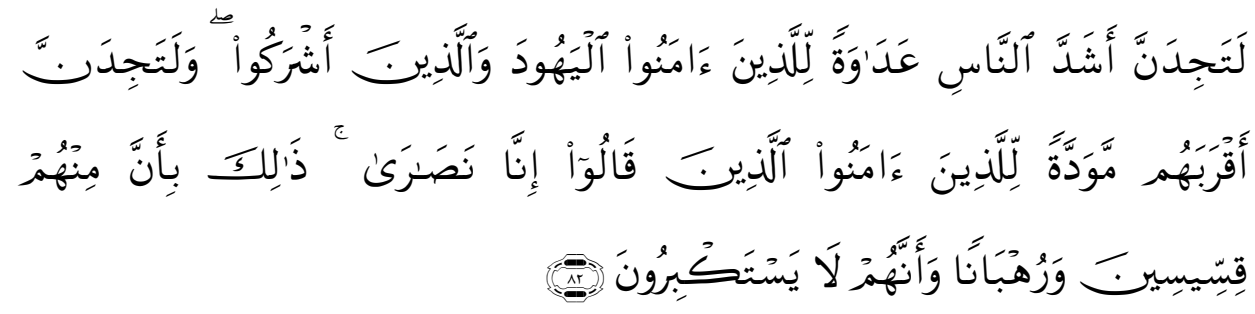

Sesunggubnya kamu dapati orang-orang yang paling keras permusubannya terhadap orang-orang yang beriman ialah orang-orang Yabudi dan orang-orang musyrik. dan Sesunggubnya kamu dapati yang paling dekat persababatannya dengan orang-orang yang beriman ialah orang-orang yang berkata: "Sesunggubnya Kami ini orang Nasrani". yang demikian itu disebabkan karena di antara mereka itu (orang-orang Nasrani) terdapat pendeta-pendeta dan rabib-rabib, (juga) karena Sesunggubnya mereka tidak menymbongkan diri.

Adanya istilah atau kata al-Nashärā dan Yahudi dalam al-Qur`an, mengindikasikan bahwa, sebelum al-Qur an diturunkan di tanah Arabi, kedua kata atau agama itu, sudah dikenal dalam kehidupan dan bahasa Arab.

c). Islam

Islam adalah nama dari sebuah agama yang dibawa Nabi Muhammad SAW. Penamaan Islam sebagai agama ternyata diberikan oleh al-Qur'an sendiri. Jadi bukan nama yang diberikan oleh orang (umat) yang mengikuti ajaran Nabi Muhammad SAW. Kata "Islam ( اسلام )" dalam al-Qur'an disebut sebanyak 6 kali, tiga di-antaranya bergandengan (dikaitkan) langsung dengan kata al-din yang artinya agama, yaitu Q.S Ali 'Imran (3) : 19 dan 85; dan Q.S al-Maidah (5): 3. Salah satu misalnya:

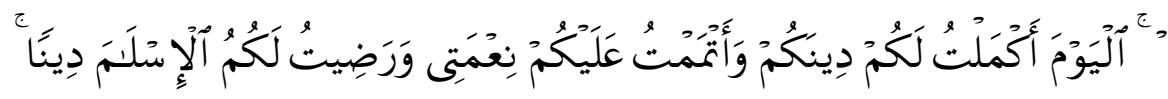

\footnotetext{
${ }^{32}$ Nuruddin Adil, Mujādilatu Ablu Kitāb fi al-Qur'an wa Sunnab Nabawiyyah, Riyâdh: Maktabah alRusyd, 2008, h. 91

33 QS 2: 62, QS 2: 111, QS 2: 113, QS 2: 120, QS 2: 135, QS 2: 140, QS 3: 67, QS 5: 14, QS 5: 18, QS 5: 51, QS 5: 69, QS 5: 82, QS 9: 30 dan QS 22: 17.

${ }^{34}$ Ibid., h. 453
} 
"Pada hari ini telah Kusempurnakan untuk kamu agamamu, dan telah Ku-cukupkan kepadamu nikmat-Ku, dan telah Ku-ridhai Islam itu Jadi agama bagimu. (Q.S alMaidah/5: 3$)^{35}$

Secara bahasa kata Islam (bahasa Arab) adalah bentuk mashdar (kata benda jadian) dari kata kerja "aslama - yuslimu". Bentuk kata kerja "aslama" ini berasal dari akar kata "salima" yang menurut kamus bahasa, makna (arti) dasarnya adalah selamat (bebas) dari bahaya atau cacat. Dari akar kata ini muncul (terbentuk) beberapa kata yaitu: "salim" yang artinya sehat; "al-silm" dan "alsalâm" artinya damai (perdamaian), ketentraman, ketenangan dan keamanan, serta; "sallama, aslama, dan istaslama" artinya tunduk, patuh, pasrah, menyerah berserah diri, dan memberi hormat. ${ }^{36}$ Dilihat dari makna-makna yang terkandung dalam arti dasar dari akar kata "salima" atau "aslama" ini, maka Islam sebagai sebuah agama yang diajarkan oleh Nabi Muhammad SAW intinya mengutamakan keselamatan, kedamaian, ketentraman dan kepatuhan kepada Tuhan.

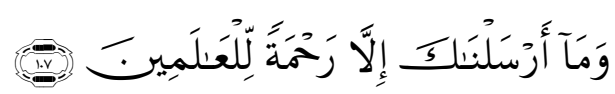

"Dan Tiadalah Kami mengutus engkau (Ya Mubammad), melainkan untuk (menjadi) rahmat bagi semesta alam. (Q.S al-Anbiya/17:107) ${ }^{37}$

Adapun "Nashara" sebagai nama sebuah agama yang disebut al-Qur'an, dalam bahasa Indonesia disebut menjadi Nasrani, Kristen atau Masehi. Kata Nashara dikaitkan dengan nama sebuah kota di sebelah utara Palestina, Nazareth. Di kota ini, Isa as atau disebut Yesus, sang pembawa agama ini dilahirkan dan dibesarkan, sehingga pengikutnya disebut umat Nasrani. Disebut juga Kristen, berasal dari kata Yunani "Khritos" yang artinya diurapi, sehingga penganutnya disebut umat Kristen (di Barat disebut Christianity). Sedangkan Masehi ada hubungannya dengan kata Messias (bahasa Ibrani) atau al-Masih (al-Masih Isa bin Maryam), yang juga artinya diurapi. Namun begitu, al-Qur'an sering pengikut agama yang dibawa nabi Isa as ini dengan sebutan Nashara. ${ }^{38}$

Selain Yahudi dan Nasrani, agama atau kelompok umat beragama yang yang ada disebut al-Qur'an adalah Majusi, al-Sabbi un. Ini terlihat dalam pernyataan al-Qur'an sebagai berikut:

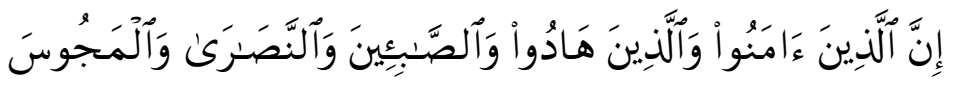

\footnotetext{
${ }^{35}$ Departemen Agama RI, Op.Cit, h. 85

36 A.W Munawwir, Op. Cit, h. 654-655

${ }^{37}$ Departemen Agama RI, Op.Cit, h. 264

${ }^{38}$ Ibid, h. 67-68
} 
58 | Al Istinbath : Jurnal Hukum Islam, Vol. 2, No. 1, 2017

"Sesunggubnya orang-orang yang beriman, orang-orang Yabudi, orang-orang Shaabiin orangorang Nasrani, orang-orang Majusi (Q.S al-Hajj/22: 17) ${ }^{39}$

Dari agama-agama yang disebut al-Qur'an, harus diakui bahwa Yahudi dan Nasrani merupakan agama yang paling banyak disinggung al-Qur'an. Kedua agama ini biasa juga disebut oleh al-Qur'an dengan sebutan "alblu kitab", maksudnya umat yang pernah ditrunkan kepadanya Kitab yang berasal dari Allah (Tuhan), yaitu Kitab Taurat kepada nabi Musa as untuk umat Yahudi, dan Kitab Injil kepada nabi Isa as untuk umat Nasrani. Khususnya dalam menaggapi sikap umat Yahudi dan Nasrani yang demikian, Islam mengharuskan umatnya memperhatikan dengan cermat apa yang disampaikan mereka, seperti terlihat dalam sebuah sabda Rasul SAW :

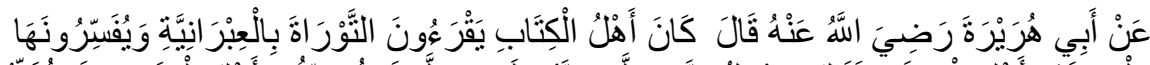

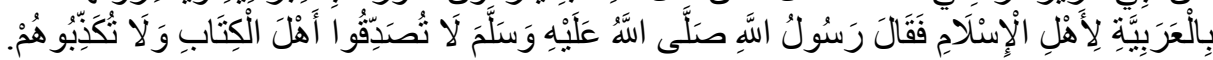
روه البخاري

Dari Abi Hurairah r.a, ia berkata (kepada Rasulullaah saw), adalah Ablu al-Kitab mereka membaca Kitab Taurat dengan bahasa Ibrani dan menafsirkannya dengan bahasa Arab untuk umat Islam. Bersabda Rasulullah Saw: "Janganlah kamu benarkan Ablu Kitab dan jangan pula kamu dustai mereka. H.R Bukhari. ${ }^{40}$

Hadis di atas, pada intinya agar umat Islam tidak apriori terhadap umat Yahudi dan Nasrani, akan tetapi harus melihatnya secara objektif, karena bagaimanapun mereka adalah umat yang telah diberi Kitab suci oleh Allah SWT. Karena itulah pada bagian lain, bila terjadi pertikaian antara Islam dengan dua agama tersebut, al-Qur'an justru menganjurkan mencari titik temu antara ketiganya, sebagaimana tertera dalam ayat berikut.

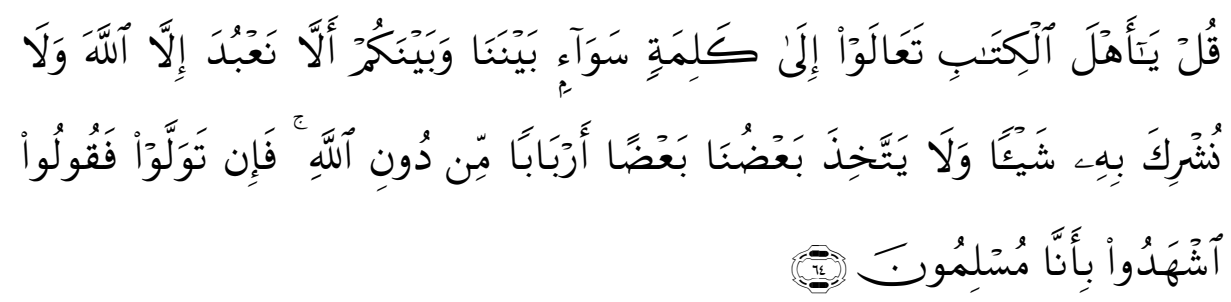

"Katakanlah: "Hai abli Kitab, Marilab (berpegang) kepada suatu kalimat (ketetapan) yang tidak ada perselisiban antara Kami dan kamu, babwa tidak kita sembah kecuali Allah dan tidak kita persekutukan Dia dengan sesuatupun dan tidak (pula) sebagian kita menjadikan sebagian yang lain sebagai Tuban selain Allab". jika mereka berpaling Maka Katakanlab kepada mereka: "Saksikanlah,

${ }^{39}$ Departemen Agama RI, Op. Cit, h. 267

${ }^{40}$ Al-Bukhari, Jami' Shabih al-Bukhari, Jilid II, Beirut: Dar al-Fikr, 2006, h. 132 
bahwa Kami adalah orang-orang yang berserah diri (kepada Allah)". (Q.S Ali $\operatorname{Imran} / 3: 64)^{41}$

\section{Ketentuan Syariat Islam Dalam Kaitannya Dengan Agama Lain}

a). Tidak ada (Dilarang/Tidak Boleh) Paksaan Dalam Agama

Pada uraian pembahasan terdahulu telah dipaparkan bahwa kecenderungan beragama merupakan gejala universal. Manusia manapun, dalam sejarah hidup manusia, hidup bersama dalam agama atau dengan perkataan lain beragama. Ringkasnya, kecenderungan pada agama adalah merupakan fitrah manusia. Potensi dan fitrah manusia untuk beragama ini telah ditegaskan dalam al-Qur'an antara lain pada surat al-A'raf/7: 172, dan surat al-Rum/30: 30. Dengan potensi dan fitrah itu, manusia tidak bisa menghindar dari ber-Tuhan (beragama). Kebebasannya adalah hanya memilihi antara satu dan lain agama. Masalahnya adalah agama mana yang ia pilih dan anut tergantung persepsi, pengetahuan yang diperolehnya. Dalam kaitan ini karena secara empirik, cara dan kemampuan mempersepsi, serta pengetahuan yang diperoleh manusia antara satu dan lainnya tidak sama, maka logis kalau kemudian melahirkan keragaman keyakinan dalam bergama. Namun begitu al-Qur'an tetap mengingatkan, bahwa fitrah ber-Tuhan (beragama) harus ditumbuh kembangkan sesuai dengan fitrahnya.

Islam sebagai sebuah agama wahyu, cukup jelas memberi tuntunan dan pedoman bagamana hidup berdampingan secara harmonis dengan umat agama lain. Hal ini, sebagaimana terlihat dalam sejarah, telah diteladani oleh Rasulullah SAW, mengenai bagaimana sikap beliau memperlakukan tetangganya, Yahudi secara baik. Adapun diantara yang menjadi prinsip dasar dalam membangun kerukunan hidup umat beragama sebagai berikut.

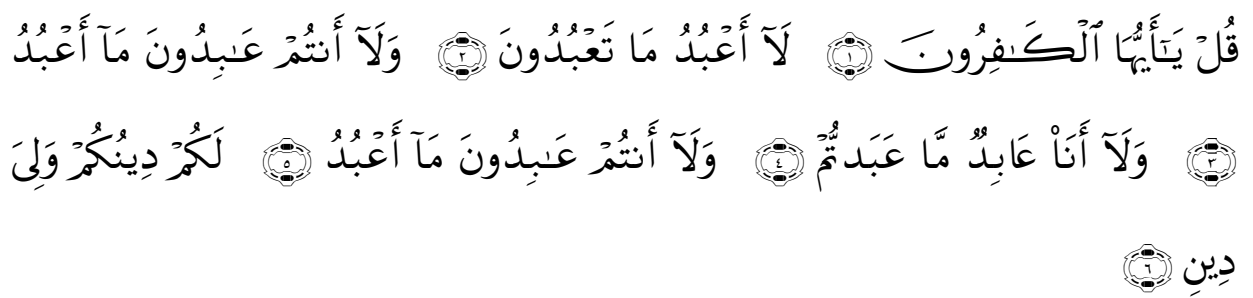

"Katakanlah: "Hai orang-orang kafir; Aku tidak akan menyembah apa yang kamu sembah. Dan kamu bukan penyembah Tuban yang aku sembah. Dan aku tidak pernah menjadi penyembah apa yang kamu sembah. Dan kamu tidak pernah (pula) menjadi

${ }^{41}$ Departemen Agama RI, Op. Cit, h. 45 
penyembah Tuban yang aku sembah. Uuntukmu agamamu, dan untukkulah, agamaku." (Q.S al-Kafirun/109: 1-6) ${ }^{42}$

Selanjutnya Q.S al-Baqarah/2: 256:

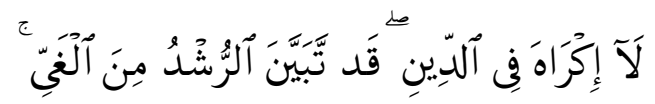

"Tidak ada paksaan untuk. (memasuki) agama (Islam); Sesungguhnya telah jelas jalan yang benar daripada jalan yang sesat."

Dua ayat al-Qur'an di atas merupakan pijakan dasar bagi umat Islam dan pemeluk agama lain untuk saling bertoleransi, sehingga merupakan kesalahan besar bagi siapapun yang menggangu umat agama lain. Menurut para ahli tafsir ${ }^{44}$, surat alKafirun 1-6 turun merupakan jawaban terhadap sebuah peristiwa pertengkaran yang terjadi antara seorang bapak yang telah memeluk agama Islam dan menginginkan dua anaknya yang agama Nasrani agar masuk Islam. Karena dua anaknya tidak dapat memindahkan kepercayaan terhadap agama yang dianutnya, maka pertengkaran terus terjadi hingga akhirnya mereka bertiga datang meminta nasehat pada Rasulullah SAW, kemudian turunlah surat al-Kafirun ini.

Ketika menafsirkan surat al-Kafirun di atas, ahli tafsir Indonesia, M. Quraish Shihab berkata:

"Setelah menegaskan tidak mungkinnya bertemu dalam keyakinan ajaran Islam dan kepercayaan Nabi Muhammad SAW dengan kepercayaan kaum yang mempersukutukan Allah, ayat di atas menetapkan cara pertemuan dalam kehidupan bermasyarakat yakni: bagi kamu secara khusus agama kamu. Agama itu tidak menyentuhku sedikitpun, kamu bebas untuk mengamalkannya sesuai kepercayaan kamu dan bagiku juga secara khusus agamaku, akupun mestinya memperoleh kebebesan untuk melaksanakannya, dan kamu tidak kamu tidak akan disentuh sedikitpun olehnya." ${ }^{45}$

Lebih lanjut beliau bahwa didahulukannya kata "lakum" dan "liya" berfungsi meng-gambarkan kekhususan, karena itu masing-masing agama biarlah berdiri sendiri dan tidak perlu dipercampurkan. Kalau din diartikan agama, maka ayat ini tidak berarti bahwa Nabi SAW diperintakan mengakui kebenaran mereka atau anutan mereka. Ayat ini hanya mempersilahkan mereka menganut apa yang mereka yakini. Apabila mereka telah mengatahui tentang ajaran agama yang benar dan mereka menolaknya serta bersikeras menganut ajaran mereka, silahkan, karena memang tidak ada paksaan dalam agama (la

\footnotetext{
${ }^{42}$ Departemen Agama RI, Op. Cit, h. 484

${ }^{43}$ Ibid., h. 33

${ }^{44}$ Ibn Katsir, Tafsir al-Qur'an al-Adbim, Juz IV, Ttp: Syirkah Nur Asia, tth, h. 559-560.

${ }^{45}$ M. Quraish Shihab, Op. Cit, Jilid, XVI, h. 581-882
} 
ikraba fi al-din). ${ }^{46}$ Jadi ayat 6 di atas, merupakan pengakuan eksistensi secara timbal balik, bagi kamu agama kamu dan bagiku agamaku.

Demikian menurut al-Qur'an sebagai sumber pokok ajaran Islam, bahwa dalam agama atau beragama tidak boleh ada unsur pakasaan. Hal itu tidak lain karena agama berkaitan dengan keyakinan. Keyakinan terbentuk menurut persepsi dan pengetahuan yang diperolehnya. Karena setiap orang memiliki argumen kebenaran terhadap apa yang diyakininya, maka menurut al-Qur'an tidak perlu ada pernyataan "agama/ keyakinannya yang paling benar, sedangkan yang lain tidak benar". Jadi pengakuan absolusitas ajaran agama tidak perlu diproklamirkan kepada semua orang atau agama lain, cukuplah menjadi sebuah keyakinan yang disampaikan atau ditanamkan dalam jiwa setiap individu. Hal demikian dilakukan penganut agama lain tidak terganggu dengan pernyataan semacam itu. Dengan demikian, kerukunan dijalankan dengan tanpa ada saling mengganggu.

Selain itu, Rasulullah SAW -pada masa itu- dihadapkan dengan persoalan bagaimana mendamaikan dua pemeluk agama di Madinah, yaitu Yahudi dan Islam, agar hidup berdampingan secara rukun dan damai. Sebagai jawaban atas persoalan-persoalan yang dihadapi Rasulullah SAW ini, maka turunlah surat alBaqarah/2: 256 yang intinya mempertegas tidak ada paksaan dalam agama (la ikrha fi adin ( tidak ada paksaan dalam agama). Ayat ini memberi jawaban berharga, bagaimana setiap umat beragama mesti hidup berdampingan dengan umat lain secara damai. Ketika menafsirkan ayat ini, seorang mufassir masyhur, Ibn Katsir dalam kitab tafsirnya menyatakan: "janganlah memaksa seorangpun untuk masuk Islam. Islam adalah agama yang jelas dan gamblang tentang semua ajaran dan bukti kebenarannya, sebingga tidak, perlu memaksakan seseorang untuk masuk ke dalamnya. Orang yang mendapat hidayah, terbuka, lapang dadanya, dan terang mata batinya pasti ia akan masuk. Islam dengan bukti yang kuat. Dan barang siapa yang buta mata batinya, tertutup penglihatan dan pendengarannya maka tidak layak baginya masuk. Islam dengan paksa." ${ }^{17}$

Dari uraian di atas, ringkasnya al-Qur'an memberi ketegasan bahwa dalam hal urusan agama dalam arti keyakinan dan peribadatan prinsipnya adalah lakum dinukum waliyadin dan laikrahfiddin. Dalam dua prinsip ini terkandung makna secara konkrit yaitu tidak mencampur adukkan keyakinan, tidak ada paksaan, menjamin kebebasan menjalankan ibadah sesuai keyaki-nannya masingmasing, dan tidak saling mengganggu.

\footnotetext{
${ }^{46}$ Loc. Cit

${ }^{47}$ Ibnu Katsir, Op. Cit, Juz I, h. 383
} 
Adapun selain urusan aqidah (keyakinan) dan peribadatan, Islam (al-Qur'an) tidak melarang membaur, bersatupadu dalam pergaulan sesama manusia dengan umat yang non muslim. Diceritakan dalam sebuah riwayat bahwa suatu ketika Asma binti Abu Bakar didatangi ibunya, Qotilah, yang masih kafir. Ia pun bertanya kepada Rasulullah SAW, "Bolehkah saya berbuat baik kepada-nya?" Rasulullah SAW menjawab, "Boleh". Kemudian turunlah ayat ke 8 Surat AlMuntahanah. ${ }^{48}$ Hadis dan ayat ini menyatakan bahwa Islam tidak melarang berbuat baik kepada orang yang tidak seagama, demikian yang diterangkan Ibnu Katsir dalam tafsirnya. ${ }^{49}$ Dengan prinsip ini maka semua berhak hidup tanpa menyebabkan tekanan atau perkosaan terhadap hak-hak orang lain. Yang diharapkan Islam dari golongan lain hanyalah menjauhkan dari permusuhan, dan tidak ada hasutan, gangguan atau tantangan terhadap jalan kehidupan yang rukun dan damai.

b) Harus Bersikap Menghargai dan Toleran Terhadap Perbedaan

Harus diakui bahwa Islam bukanlah satu-satunya agama "samawiy" yang diturunkan olah Tuhan (Allah). Dalam sistem teologi Islam, sebagaimana ditemukan banyak ayat al-Qur'an, bahwa beriman kepada Kitab dan Nabi atau Rasul termasuk dalam enam perkara (arkan al-iman) yang wajib dipercayai oleh umat Islam. Beriman kepada Kitab Suci dan Nabi yang dimaksudkan oleh alQur'an, tidak hanya kepada Kitab Suci al-Qur'an yang diturunkan kepada Nabi Muhammad SAW akan tetapi juga Kitab Suci yang telah diturunkan kepada Nabi dan Rasul sebelum Muhammad SAW. ${ }^{50}$ Kitab-Kitab sebelumnya itu antara lain, Kitab Taurat yang diturunkan kepada Nabi Musa a.s dan sekarang menjadi Kitab Suci agama Yahudi, dan Kitab Injil yang pernah diturunkan kepada Nabi Isa a.s yang sekarang menjadi Kitab Suci agam Kristen (Nasrani). Begitupula, Kitab Suci umat Islam, al-Qur'an, memperingatkan bahwa tidak boleh ada perbedaan dalam mengimani para Nabi dan Rasul yang pernah diutus oleh Allah SAW, semua wajib diimani dan hormati. ${ }^{51}$

\footnotetext{
48 Allah tidak melarang kamu untuk berbuat baik dan Berlaku adil terhadap orang-orang yang tiada memerangimu karena agama dan tidak (pula) mengusir kamu dari negerimu. Sesunggubnya Allah menyukai orang-orang yang Berlaku adil

${ }^{49}$ Ibn Katsir, juz IV, Op. Cit, h 349.

${ }^{50}$ Q.S al-Baqarah/2: 3 (Dan mereka yang beriman kepada kitab (Al Quran) yang telab diturunkan kepadamu dan Kitab-Kitab yang telab diturunkan sebelummu, serta mereka yakin akan adanya (kebidupan) akbirat).

${ }^{51}$ Q.S a-Baqarah / 2 : 285 (Rasul telab beriman kepada Al Quran yang diturunkan kepadanya dari Tubannya, demikian pula orang-orang yang beriman. semuanya beriman kepada Allah, malaikat-malaikatNya, kitab-kitab-Nya dan rasul-rasul-Nya. (mereka mengatakan): "Kami tidak membeda-bedakan antara seseorangpun (dengan yang lain) dari rasul-rasul-Nya", dan mereka mengatakan: "Kami dengar dan Kami taat." (mereka berdoa): "Ampunilah Kami Ya Tuhan Kami dan kepada Engkaulah tempat kembali."
} 
Dari sudut pandangan teologis ajaran Islam di atas, sesungguhnya tidak ada alasan untuk tidak menunjukkan sikap mengormati, toleransi terhadap ajaran agama-agama yang terdapat dalam Kitab-Kitab Suci yang telah diajarkan oleh para Nabi dan Rasul sebelum Nabi Muhammad SAW. Itu berarti kerukanan beragama sebenarnya merupakan akibat wajar atau konsekuensi logis dari sistem keimanan itu sendiri.

Nabi Muhammad SAW diperintahkan Allah untuk menegaskan bahwa beliau bukan orang yang pertama di kalangan utusan Allah SWT. ${ }^{52}$ Juga ditegaskan bahwa Nabi Muhammad SAW itu tidak lain hanya seorang Rasul, yang sebelumnya telah lewat Rasul-Rasul yang lain. ${ }^{53}$ Karena itu Nabi Muhammad SAW menegaskan bahwa agama para Rasul itu semuanya adalah satu dan sama, sekalipun syari'atnya berbeda-beda. ${ }^{54}$ Kesatuan agama para Nabi dan Rasul itu, sebagaiamana disebutkan dalam al-Qur'an adalah karena semuanya berasal dari pesan atau ajaran Allah SWT.

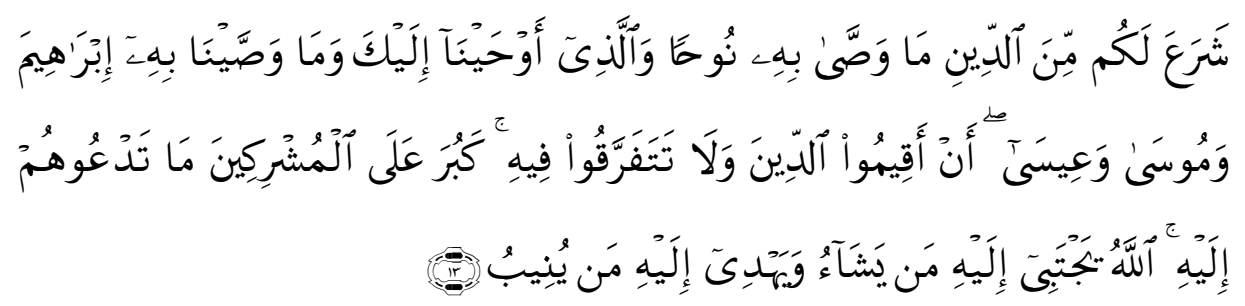

'Dia telah mensyari'atkan bagi kamu tentang agama apa yang telah diwasiatkan-Nya kepada Nuh dan apa yang telah Kami wahyukan kepadamu dan apa yang telah Kami wasiatkan kepada Ibrabim, Musa dan Isa Yaitu: Tegakekanlah agama dan janganlah kamu berpecah belah tentangnya. Amat berat bagi orang-orang musyrik agama yang kamu seru mereka kepadanya. Allah menarik kepada agama itu orang yang dikehendaki-Nya dan memberi petunjuk kepada (agama)-Nya orang yang kembali (kepada-Nya). (Q.S al-Syura/43:13) $)^{55}$

Berdasarkan ayat di atas terlihat bahwa Islam mengajarkan agar umat Islam tidak membeda-bedakan agama-agama yang pernah dibawa oleh para

\footnotetext{
${ }^{52}$ Q.S al-Ahqaf/46 : 9 (Katakanlab: "Aku bukanlah Rasul yang pertama di antara Rasul-rasul dan aku tidak mengetahui apa yang akan diperbuat terbadapku dan tidak. (pula) terbadapmu. aku tidak. lain banyalah mengikuti apa yang diwahyukan kepadaku dan aku tidak. lain hanyalah seorang pemberi peringatan yang menjelaskan").

${ }^{53}$ Q.S Ali Imran/ 3: 144 (Muhammad itu tidak lain hanyalah seorang rasul, sunggub telab berlalu sebelumnya beberapa orang rasul).

${ }^{54}$ Rasulullah SAW bersabda: "Diantara umat manusia aku lebih berbake atas Isa Putra Maryam di dunia dan akbirat. Para Nabi adalab bersaudara tunggal bapak, ibu mereka berbeda-beda, namun agama bereka satu." H.R Bukhari.

${ }^{55}$ Departemen Agama RI, Op.Cit, h. 386
} 
Nabi yang pernah diutus Allah dalam arti tidak merasa lebihkan dan atau merendahkan suatu agama. Kalaupun dilihat ada perbedaan, maka perbedaan antara berbagai agama itu hanyalah dalam bentuk-bentuk jalan (syir'ah atau syariab) menempuh jalan itu. Dan perbedaan dari sisi ini hendaknya tidak menjadi halangan bahkan menjadi pangkal untuk berlomba-lomba menuju ke berbagai kebaikan. Terhadap adanya perbedaab yang dipersoalkan, al-Qur'an menjelaskan bahwa nanti di Hari Akhirat Allah akan menjelaskan semua itu.

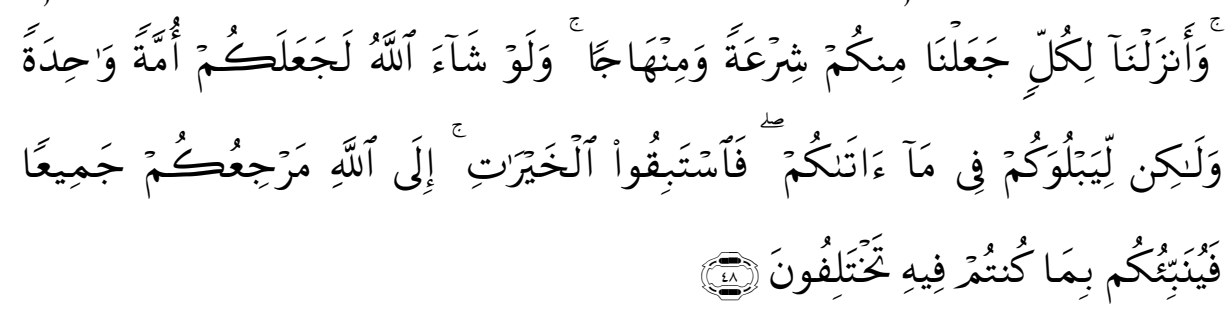

"Bagi tiap-tiap umat diantara kamu, Kami berikan aturan dan jalan yang terang. Sekiranya Allah menghendaki, niscaya kamu dijadikan-Nya satu umat (saja), tetapi Allab hendak menguji kamu terhadap pemberian-Nya kepadamu, Maka berlombalombalah berbuat kebajikan. hanya kepada Allah-lab kembali kamu semuanya, lalu diberitahukan-Nya kepadamu apa yang telah kamu perselisibkan itu." (Q.S alMaidah: 48$)^{56}$

Kalaupun terjadi perbedaan, maka untuk mengurangi resistensinya alQur'an mengan-jurkan agar dibangun "dialog lintas agama" dengan mencari titik temu kebenaran ada pada setiap ajaran agama. Untuk ini al-Qur an menyatakan:

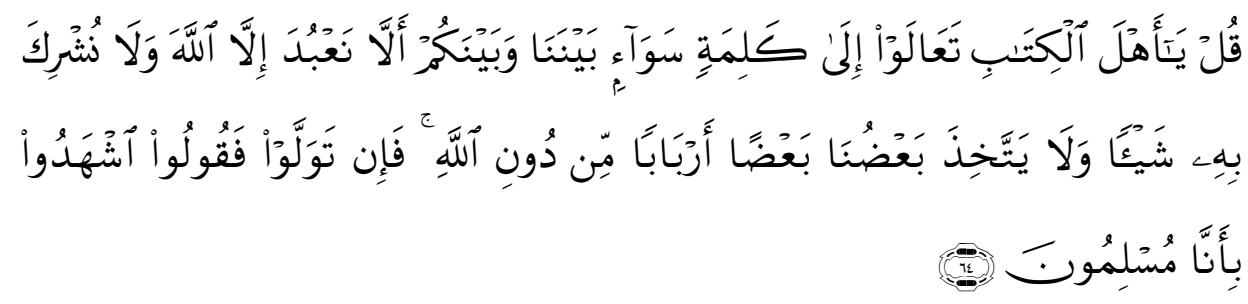

Katakanlab: "Hai abli Kitab, Marilah (berpegang) kepada suatu kalimat (ketetapan) yang tidak ada perselisiban antara Kami dan kamu, bahwa tidak kita sembah kecuali Allah dan tidak kita persekutukan Dia dengan sesuatupun dan tidak (pula) sebagian kita menjadikan sebagian yang lain sebagai Tuban selain Allab". jika mereka berpaling Maka Katakanlah kepada mereka: "Saksikanlah, bahwa Kami adalah orang-orang yang berserah diri (kepada Allah)". (Q.S Ali Imran/3:64) ${ }^{57}$

${ }_{56}^{56}$ Departemen Agama RI, Op. Cit, h. 92

${ }^{57}$ Ibid., h. 45 
Ringkasnya, setiap muslim wajib percaya kepada semua Nabi dengan semua yang dibawanya dalam Kitab-Kitab Suci, tanpa membeda-bedakan seorangpun diantara mereka, sebagaimana dinyatakan al-Qur'an:

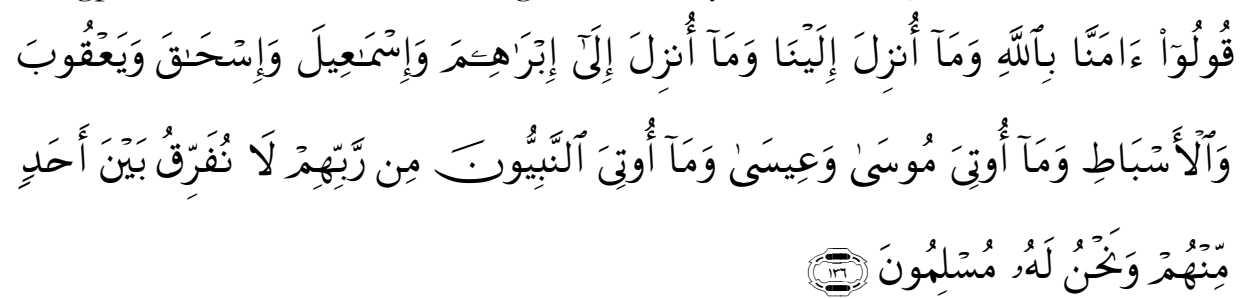

'Katakanlah (hai orang-orang mukmin): "Kami beriman kepada Allah dan apa yang diturunkan kepada Kami, dan apa yang diturunkan kepada Ibrabim, Isma'il, Ishaq, Ya'qub dan anak cucunya, dan apa yang diberikan kepada Musa dan Isa serta apa yang diberikan kepada nabi-nabi dari Tubannya. Kami tidak membeda-bedakan seorangpun diantara mereka dan Kami hanya tunduk, patuh kepada-Nya" (Q.S al-Baqarah/2: 136)..$^{58}$

Memang merupakan suatu kenyataan yang tidak dapat diingkari bahwa tidak semua ajaran dan kitab-kitab para nabi itu terpelihara dengan baik sepanjang masa sehingga mungkin mengalami pengubahan-pengubahan tidak sah oleh tangan-tangan manusia. Kerena itu al-Qur'an diturunkan pertama-tama untuk mendukung kebenaran Kitab Suci yang ada di tangan umat manusia dan melindunginya ${ }^{59}$ dan untuk meluruskan mana yang telah menyimpang karena ulah tangan manusia itu. Namun pada dasarnya al-Qur'an itu tetap mengakui Kitab-Kitab Suci yang lalu itu mengandung kebenaran yang harus dijalankan oleh para pengikutnya. Karena itu, misalnya, Allah memerintahkan kaum Yahudi dan Nasrani untuk dengan kesungguhan menjalankan ajaran yang ada dalam Kitab Suci mereka masing-masing.

${ }^{58}$ Departemen Agama RI, Op. Cit, 16

${ }^{59}$ Q.S al-Maidah/5: 48 (dan Kami telah turunkan kepadamu Al Quran dengan membawa kebenaran, membenarkan apa yang sebelumnya, Yaitu Kitab-Kitab (yang diturunkan sebelumnya) dan batu ujian terbadap Kitab-Kitab yang lain itu; Maka putuskanlah perkara mereka menurut apa yang Allab turunkan dan janganlah kamu mengikuti hawa nafsu mereka dengan meninggalkan kebenaran yang telah datang kepadamu. untuk tiap-tiap umat diantara kamu, Kami berikan aturan dan jalan yang terang. Sekiranya Allab menghendaki, niscaya kamu dijadikan-Nya satu umat (saja), tetapi Allah hendak menguji kamu terhadap pemberian-Nya kepadamu, Maka berlomba-lombalah berbuat kebajikan. hanya kepada Allab-lab kembali kamu semuanya, lalu diberitabukan-Nya kepadamu apa yang telab kamu perselisibkan itu. Ibid., h. 92 
66 | Al Istinbath : Jurnal Hukum Islam, Vol. 2, No. 1, 2017

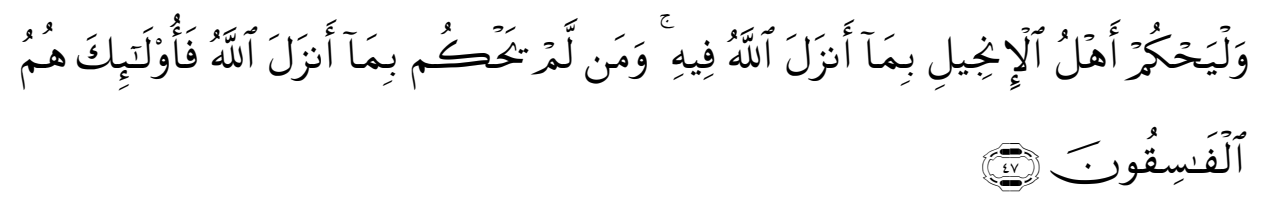

"Dan hendaklah orang-orang pengikut Injil, memutuskan perkara menurut apa yang diturunkan Allah didalamnya. Barangsiapa tidak memutuskan perkara menurut apa yang diturunkan Allah, Maka mereka itu adalab orang-orang yang fasik" (Q.S alMaidah/5: 47) ${ }^{60}$

Berpangkal dari berbagai ayat-ayat dan pandangan asasi di atas maka alQur'an sesungguhnya menyuruh kaum beriman atau umat Islam harus menghormati semua pengikut Kitab Suci (Abl Kitab, people of the book). Demikian al-Qur'an telah meletakkan dasar-dasar (prinsip) toleransi untuk terciptanya kerukunan hidup anar umat beragama. Dan prinsip-prinsip tersebut telah dicontohkan oleh Rasulullah SAW, baik terhadap jirannya yang beragama Yahudi, maupun dalam hal pergaulan, seperti melakukan transkasi dagang. Dalam sejarah terlihat, meskipun Nabi SAW bersikap keras dan tegas kerhadap kaum musyrik, namun beliau tetap menjaga pergaulan yang sangat baik dengan kaum Nasrani yang lurus. Terhadap mereka itu, ajaran al-Qur'an mengatakan bahwa umat Islam tidak boleh berdebat kecuali dengan cara yang lebih baik, dari segi cara maupun isinya. Dan terhadap mereka yang lurus itu, umat Islam tidak dilarang untuk bergaul dengan baik dan bersikap jujur.

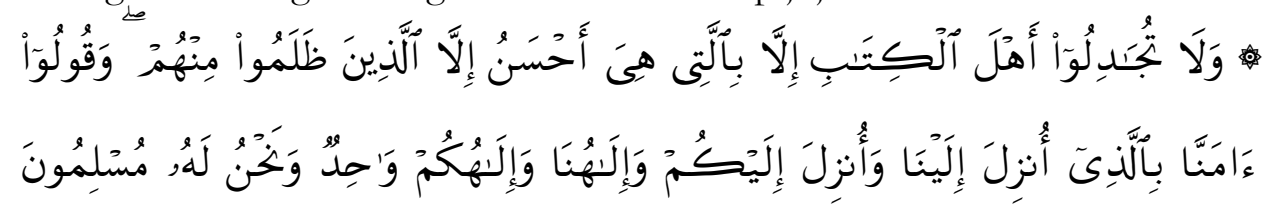

"Dan janganlah kamu berdebat dengan Abli Kitab, melainkan dengan cara yang paling baik, kecuali dengan orang-orang zalim di antara mereka, dan Katakanlah: "Kami telah beriman kepada (kitab-kitab) yang diturunkan kepada Kami dan yang diturunkan kepadamu; Tuban Kami dan Tubanmu adalab satu; dan Kami hanya kepada-Nya berserah diri"(Q.S al-Ankabut/29: 46) ${ }^{61}$

${ }^{60}$ Ibid., h. 92

${ }^{61}$ Departemen Agama RI, Op. Cit, h.231 


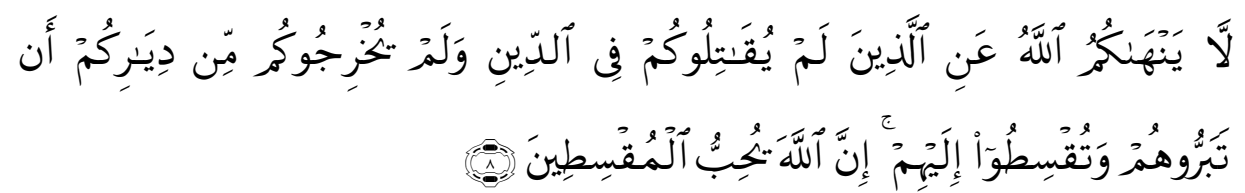

"Allah tidak melarang kamu untuk berbuat baik dan Berlaku adil terhadap orangorang yang tiada memerangimu karena agama dan tidak (pula) mengusir kamu dari negerimu. Sesunggubnya Allah menyukai orang-orang yang Berlaku adil.'(Q.S alMumtanahan/60: 8) ${ }^{62}$

Atas pertimbangan itu semua, maka ketika umat Islam di Madinah diizinkan untuk berperang guna membela diri (setelah selama di Mekkah sebelumnya dilarang perang), serta bertu-juan membela kebenaran dan melindungi lembaga-lembaga keagamaan seperti biara, gereja dan mesjid.

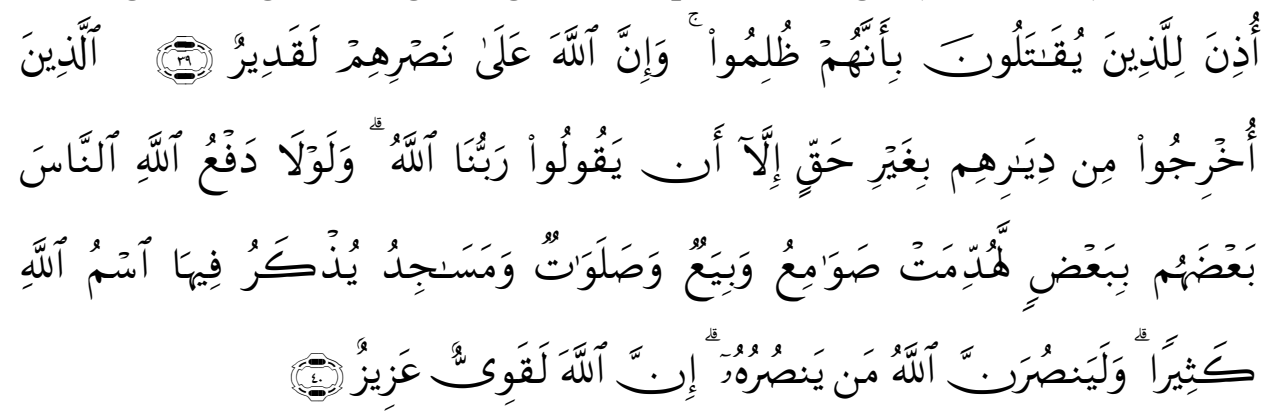

"Telah diizinkan (berperang) bagi orang-orang yang diperangi, karena Sesunggubnya mereka telab dianiaya. dan Sesunggubnya Allab, benar-benar Maba Kuasa menolong mereka itu. (yaitu) orang-orang yang telah diusir dari kampung halaman mereka tanpa alasan yang benar, kecuali karena mereka berkata: "Tuban Kami hanyalab Allab". dan Sekiranya Allab tiada menolak (keganasan) sebagian manusia dengan sebagian yang lain, tentulah telah dirobohkan biara-biara Nasrani, gereja-gereja, rumahrumah ibadat orang Yahudi dan masjid- masjid, yang di dalamnya banyak disebut nama Allah. Sesunggubnya Allah pasti menolong orang yang menolong (agama)-Nya. Sesunggubnya Allab benar-benar Maha kuat lagi Maha perkasa. (Q.S al-Hajj/2: 39$41)^{63}$

Terhadap mereka yang lurus itu, Nabi SAW bersikap sangat ramah, sampai-sampai ketika suatu delegasi Kristen dan Najran (sebuah kota di selatan Makkah, dekat dengan perbatasan Yaman) datang menemui Nabi SAW di Madinah, dan selesai pengadakan perundingan dengan Nabi SAW, beliau menginzinkan mereka itu melakukan kebaktian di mesjid beliau (mesjid Nabawiy). Ada kalangan dari para sahabat Nabi SAW yang mencoba menghalangi

\footnotetext{
${ }^{62}$ Ibid.h 439

${ }^{63}$ Ibid.h. 269
} 
mereka, dan hendak membawa mereka keluar. Tapi justru Nabi SAW melarang sahabat itu dan bersabda : "Biarkan mereka.". Berdasarkan peristiwa itu Ibn Qayyim menyimpulkan bahwa Ahli Kitab dibolehkan masuk masjid dan mengadakan kebaktian di situ dengan disakasikan kaum Muslimin, asalkan tidak dijadikan kebiasaan. ${ }^{64}$

Selain memberi petunjuk menegani dasar bertoleransi, Islam juga mengajari manusia tidak bermusuhan dan tidak membuat kerukasan, sebaliknya menganjurkan untuk saling suka memaaf-kan. Dalam situasi perang sekalipun, Islam memberi pedoman agar umat Islam tidak berbuat kejahatan terhadap musuh sekalipun, tetapi tetap mengembangkan sikap toleran. Misalnya ketika dalam peperangan, ada musuh yang minta perlindungan pada pihak Islam, maka harus dilindungi, dan jika ia ingin kembali kepada bangsanya, ia pun harus dikembalikan kepada bangsanya dengan penuh keamanan. Ini merupakan salah satu contoh bentuk toleransi yang diajarkan dalam Islam. Contoh lainnya adalah etika perang yang dibangun dalam perang adalah dilarang menangkap atau membunuh para, pendeta, guru-guru agama, sarjana, orang-orang tua, wanita dan anak-anak. Dilarang merusak barang-barang atau harta benda, tumbuhtumbuhan dan binatang-binatang, tempat-tempat ibadah. Perang harus dibatasi pada ukuran batas-batas kemanusiaan. Q.S al-Taubah: 6 menjelaskan:

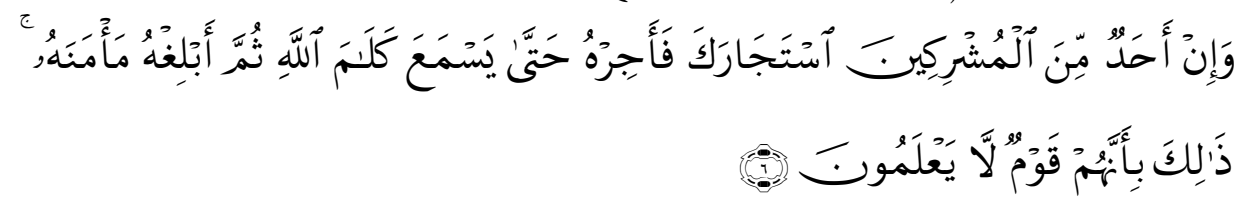

"Dan jika seorang diantara orang-orang musyrikin itu meminta perlindungan kepadamu, Maka lindungilah ia supaya ia sempat mendengar firman Allah, kemudian antarkanlah ia ketempat yang aman baginya. demikian itu disebabkan mereka kaum yang tidak mengetahui." (Q.S al-Taubah/9: 6) ${ }^{65}$

Demikianlah dalam perang saja Islam tetap menganjurkan untuk memiliki sikap toleransi. Hal ini menjadi cermin, apalagi dalam kehidupan normal dalam kehidupan sehari-hari. Menyimak ayat-ayat dan ulasan di atas dapat dipahami bahwa Islam sangat memiliki tolerasi dan menginginkan terciptanya kerukunan hidup antar umat beragama.

\section{Manusia merupakan ummat "wahidah"}

${ }^{64}$ Ibn Qayyim, Zad al-Ma'ad fi Hady Khair al-Ibad, Jilid III, Beirut: Dar al-Fikr, 1972, h. 3842

${ }^{65}$ Derpartemen Agama RI, Op. Cit, h. 150 
Setelah al-Qur'an menetapkan dan menjamin kebebasan dan tidak ada paksaan dalam beragama serta menanamkan keimanan kepada semua Nabi dan Rasul yang pernah diutus Allah (Tuhan) tanpa membeda-bedakannya sebagai dasar pijakan membangun kerukunan hidup ber-agama, maka selanjutnya alQur'an memiliki pandangan universal terhadap eksistensi manusia itu sendiri yang harus dihormati oleh sesama manusia karena statusnya sebagai manusia. Adapun prin-sip dasar pandangan al-Qur'an ini antara lain:

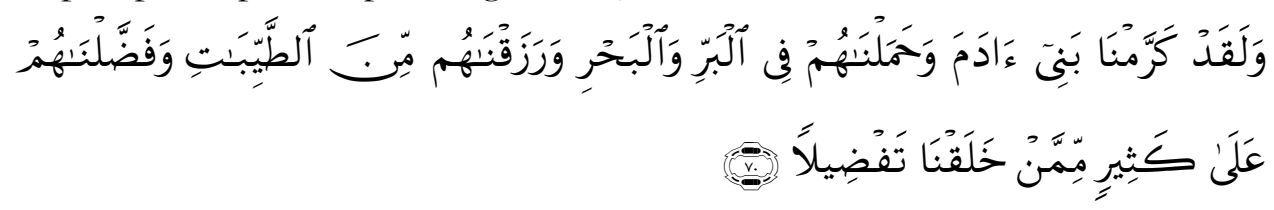

"Dan Sesunggubnya telah Kami muliakan anak-anak Adam, Kami angkut mereka di daratan dan di lautan, Kami beri mereka reqki dari yang baik-baik dan Kami lebibkan mereka dengan kelebihan yang sempurna atas kebanyakan makbluk yang telah Kami ciptakan." (Q.S al-Isra'/17: 70) ${ }^{66}$

Selanjutnya:

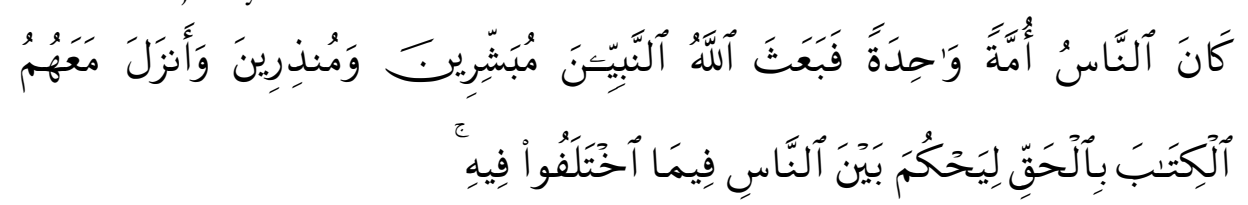

"Manusia itu adalah umat yang satu. (setelah timbul perselisiban), Maka Allah mengutus Para Nabi, sebagai pemberi peringatan, dan Allah menurunkan bersama mereka kitab yang benar, untuk memberi keputusan di antara manusia tentang perkara yang mereka perselisibkan. tidaklah berselisib tentang kitab itu melainkan orang yang telah didatangkan kepada mereka Kitab, (Q.S al-Baqarah/2:213) ${ }^{67}$

Dua ayat di atas menjadi dasar penting bagi manusia untuk saling menghormati dan menghargai esksistensi kemanusiaannya. Dikatakan bahwa manusia adalah umat yang satu (ummatan wabidah) karena semua manusia adalah keturunan Adam dan Hawa. Karena itu tidak disangsikan lagi bahwa semua umat manusia adalah satu keluarga, melalui jaringan hubungan kekerabatan yang amat luas. Keluarga besar umat manusia ini kemudian berpencar, menyebar ke seluruh dunia dengan berbagai bentuk suku dan ras (bangsa). Al-Qur'an menyatakan:

${ }^{66}$ Departemen Agama RI, Op. Cit, 231
${ }^{67}$ Ibid., h. 26 


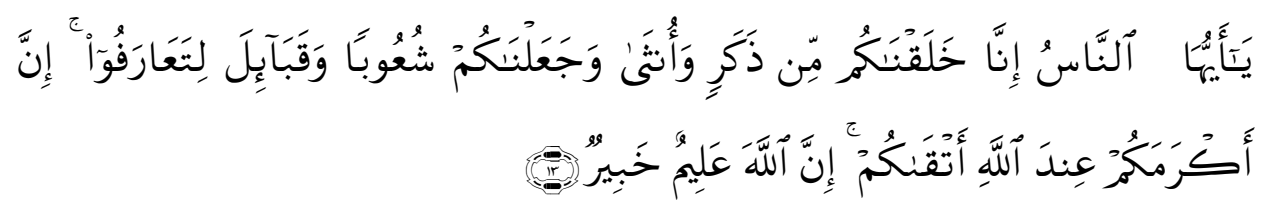

"Hai manusia, Sesunggubnya Kami menciptakan kamu dari seorang laki-laki dan seorang perempuan dan menjadikan kamu berbangsa - bangsa dan bersuku-suku supaya kamu saling kenal-mengenal. Sesunggubnya orang yang paling mulia diantara kamu disisi Allab ialah orang yang paling taqwa diantara kamu. Sesunggubnya Allah Maba mengetahui lagi Maha Mengenal”. (Q.S al-Hujarat/49:13) ${ }^{68}$

Pernyataan “ agar kalian saling mengenal " (lita'ârafû) memiliki dua arti. Pertama, adalah saling mengetahui satu sama lain, dan kedua; adalah mempererat hubungan satu sama lain atas dasar landangan yang sehat dan dapat diterima etika. Dalam hal ini, penting untuk dikemukakan bahwa konsep saling mengenal itu merupakan suatu makna kerjasama dan hidup bersama. ${ }^{69}$ Jadi, persatuan manusia mengharuskan adanya persahatan, kerjasama, dan saling pengertian, bukan permusuhan akibat dari perbedaan.

Dari ayat dan penjelasan di atas dapat dilihat bahwa kerukunan hidup beragama tidak hanya berlandaskan idiologis, yakni iman, akan tetapi juga berlandasakan pada pandangan kemanusiaan (humanisme). Dari sudut pandang kedua ini, maka sesungguhnya, kerukunan merupakan hasil dari adanya pandangan al-Qur'an mengenai umat manusia, suatu sudut pandang yang dilandasi dua kriteria. Pertama, harus ada ketetapan yang sangat jelas mengenai tujuan di balik keberadaan manusia serta komitmen untuk menggunakan cara dan sarana yang sehat dalam mencari tujuan tersebut. Kedua, harus ada penyamarataan kesadaran dan pemahaman di dalam diri manusia bahwa eksistensi manusia bersifat transendental, yakni bukan saja menyangkut urusan duniawi yang fana tetapi juga kehidupan Akhirat kelak. Kerukunan harus dibangun berdasarkan bentuk kerjasama yang disadari dengan sikap saling percaya dan saling menghormati serta bertujuan untuk mencapai tujuan-tujuan yang telah disepakati pihak-pihak yang bukan saja sama-sama menginginkan kerukunan tetapi juga ingin melaksanakannya dengan penuh kepercayaan, kebebasan dalam berhasrat dan dalam menentukan pilihan.

Lebih lanjut, menurut Muhammad al-Ghazali ${ }^{70}$, kurukunan hidup beragama harus mencakup tiga aspek utama. Pertama, bersepakat untuk

${ }^{68}$ Ibid., h. 412

${ }^{69}$ Abd 'Aziz Utsman al-Waijri, Islam dan Kerukunan Antar Umat Bergama di Abad 21, dalam

Majalah Harmoni, Vol. III, no. II, 2004, h. 26

${ }^{70}$ Muhammad al-Ghazali, Sounding Alm Against Evangelists, Kairo: Sahwa Publishing House, 1991, h. 13 
menghapuskan segala hal yang bersifat mencemarkan kemuliaaan dan kebesaran Tuhan. Kedua, bersepakat bahwa Tuhan (Allah) memilih para Rasul-Nya dari kalangan umat manusia yang terkenal dengan kesalehan, kejujuran serta keadilan. Ketiga, mengembalikan masalah-masalah kontroversial kepada landasan yang kuat dan menyakinkan supaya secara berangsur-angsur dapat meletakkan suatu landasan umum yang dapat diterima oleh berbagai agama.

Barangkali sebagai bukti dan contoh sikap kerukuan hidup beragama yang digagas al-Qur'an, sekaligus mungkin dapat menjadi teladan dapat dilihat berbagai kasus yang terjadi dalam sejarah Islam, utamanya ketika umat Islam menalukkan wilayah-wilayah non Muslim. Misalnya ketika Islam berhasil menalukkan kota suci Yurussalem yang mayoritas beragama Kristiani. Diceritakan bahwa, ketika Umar bin Khaththab memasuki Yurussalem (alQuds) sebagai penakluk, ia disambut oleh Pendeta dan mengajaknya untuk mengelilingi kota tersebut sehingga mereka sampai di Gereja Kebangkitan, lalu keduanya masuk. Ketika masuk waktu sholat tiba, Umar mengatakan kepada sang Pendeta bahwa dia mau menunaikan sholat. Sang Pendeta menjawab : “ Tuan boleh sembahyang di tempat mana Tuan sedang duduk sekarang." Namun karena sadar bahwa dia duduk persis di tengah-tengah Gereja, maka Umar khawatir bahwa kaum Muslimin kelak akan mengikuti caranya ini. Mungkin mereka akan berkata: "Karena Umar telah melaksanakan sholat di sini, maka kamipun semua berbak untuk melakukan hal yang sama." Bahkan boleh jadi mereka akan menjadikan gereja sebagai milik mereka dengan cara merampasnya secara paksa walaupun melanggar Perjanjian yang telah ditetapkan Umar, dimana ditegaskan bahwa umat Islam harus menghormati umat Kristen dan bahwa Gereja-Gereja Kristen hanya untuk mereka sendiri. Mereka mungkin akan mengira bahwa apa yang telah dilakukan Umar mereupakan amandemen bagi Perjanjian tersebut. Karena itu, Umar keluar dari Gereja tersebut dan melaksanakan sholat di gerbangnya. Namun, dia memerintahkan untuk menuliskan bahwa di sekitar bekas tempat sholatnya tidak boleh melakukan sholat beramaah dan tidak boleh pula dikumandangkan adzan. Umar kemudian pergi menuju sebuah bukit Batu dan mendirikan sebuah mesjid di sana. ${ }^{71}$

Demikianlah al-Qur'an, sebagai Kitab Suci sesungguhnya telah meletakkan konsep yang kuat dan tegas untuk saling toleran dan hidup rukun terhadap adanya perbedaan dan keragaman keyakinan (agama). Dan itu semua telah dicontohkan tidak hanya oleh Nabi Muhammad SAW tetapi juga oleh para sahabatnya (al-sabiqun al-awwalun). Toleransi dan kerukunan hidup antar umat beragama yang digagas al-Qur'an, dalam sejarah Islam, terlihat bukan saja menjadi bagian dari keyakinan yang kuat mewarnai tingkah laku, tetapi juga

${ }^{71}$ Abd al-Aziz Utsman, Op. Cit, h. 30-31 
merupakan sudah menjadi suatu cara hidup orang Islam baik pribadi maupun kelompok.

\section{Penutup}

Mengakhiri tulisan ini ada beberapa hal yang dapat disimpulkan. Pertama, Islam yang terambil dari akar kata bahasa Arab "salima" (yang artinya selamat dan damai) adalah agama yang sangat mementingkan ajaran tentang kedamian, ketentraman. Karenanya Islam sangat menentang keras segala sikap dan perbuatan destruktif yang merusak kedamaian, ketentraman dan keselamatan pada diri sendiri dan orang lain.

Kedua, untuk terciptanya kedamaian hidup dalam kaitannya dengan sesama pemeluk agama yang berbeda setidaknya ada empat prinsip utama yang diletakkan Islam sebagai dasar pijakan membangun kerukunan hidup beragama. Prinsip pertama ialah "lâ ikraha fi dîn" dan prinsip kedua "lakum dinukum waliyadin". Dalam dua prinsip ini al-Qur'an menekankan tidak boleh ada kompromi dan paksaan dalam urusan keyakinan dan peribadatan, melainkan harus ada kebebasan. Al-Qur'an meletakkan dua prinsip ini karena agama terbentuk dalam diri seseorang pada hakikatnya dipengaruhi oleh persepsi dan pengetahuan yang kemudian menjadi keyakinan. Prinsip ketiga adalah toleran "tasamub" terhadap agama yang berbeda. Di dalam prinsip ini terkandung nilai saling menghargai, menghormati dan keadilan. Prinsip ini sesungguhnya terbangun dari sistem keimanan yang ditanamakan al-Qur'an. Yaitu al-Qur`an menyuruh manusia yang beriman kepada seluruh Nabi dan Rasul yang pernah diutus Tuhan (Allah), baik yang sempat tersebut di dalam al-Qur'an maupun yang tidak tersebut, dengan tanpa membeda-bedakan (diskriminatif) antar satu dengan yang lainnya. Seluruh ajaran para Nabi dan Rasul pada hakekatnya adalah satu. Perbedaanya terletak pada bentuk ibadat dan peraturan-peraturannya yang disesuaikan dengan kerangka pikir, zaman dana tempat suatu bangsa (umat). Adapun prinsip keempat adalah "universilitas manusia/ummatan wabidab". Prinsip ini diletakkan al-Qur'an karena; (1) Tuhan telah memuliakan manusia dari makhluk Tuhan lainnya; (2) eksistensi manusia ialah sebagai wakil Tuhan untuk mencip-takan kemakmuran di dunia, dan; (3) pada asalnya menusia berasal dari asal (keturunan) yang satu, Adam dan Hawa. Kesadaran kesatuan umat manusia tentunya mengharuskan adanya persahabatan bukan permusuhan. Jadi ringkasnya konsep kerukunan hidup beragama dalam al-Qur'an terbangun oleh dasar ideologis, yakni berasaskan iman, akan tetapi juga oleh dasar humanisme.

\section{Daftar Pustaka}


Abd 'Aziz Utsman al-Waijri, Islam dan Kerukunan Antar Umat Bergama di Abad 21, dalam Majalah Harmoni, Vol. III, no. II, 2004

Ahmad Warson Munawwir, Kamus al-Munawwar, Yogyakarta: Pustaka Progresif, 1997

Abdurrahman Madjrie, Meluruskan Aqidah, Jakarta, Khairul Bayan, 2003

Al-Bukhari, Jami' Shahih al-Bukhari, Jilid II, Beirut: Dar al-Fikr, 2006

Badan Litbang Agama dan Diklat Keagamaan, Kompilasi Peraturan PerundangUndangan Kerukunan Hidup Umat Beragama, Jakarta: Depatemen Agama RI, 2003

Budhy Munawar Rachman, Mengembalikan Kerukunan Umat Beragama, dalam Majalah Ihklas Beramal Departemen Agama, Nomor 47 Tahun X 2007, h. 45.

Dadang Kahmad, Metode Penelitian Agama, Bandung: Pustaka Setia, 2000

Dawam Raharjo, Ensiklopedi Al-Qur'an: Tafsir Sosial Berdasarkan KonsepKonsep Kunci, Jakarta: Temprint, 1996,

Departeman Agama RI, Pedoman Dasar Kerukunan Hidup Beragama, Proyek Pembinaan Kerukunan Hidup Beragama, 1979

..,Pedoman Dasar Kerukunan Hidup Beragama, Jakarta: Proyek Pembinaan Kerukunan Hidup Beragama Depag RI, 1979

Al-Qur'an dan Terjemahnya, Semarang: Toha Putra, 1998

Departemen Pendidikan dan Kebudayaan RI, Kamus Besar Bahasa Indonesia, Jakarta: Balai Pustaka, 1994

Ibn Katsir, Tafsir al-Qur'an al-Azhim, Mesir: Isa al-Baby al-Halabiy, tth.

Ibn Qayyim, Zad al-Ma'ad fi Hady Khair al-Ibad, Jilid III, Beirut: Dar al-Fikr, 1972

Luwis Ma luf, Al-Munjid fi al-Lughah, Beirut: Dar al-Masyriq, 1986

Mahmud Yunus, Kamus Arab Indonesia, Jakarta, tp, 1986 
74 | Al Istinbath : Jurnal Hukum Islam, Vol. 2, No. 1, 2017

Muhammad Fu'ad 'Abd al-Baqiy, selanjutnya ditulis 'Abd al-Baqiy, Al-Mu'jam al-Mufahras Lialfazh al-Qur`an al-Karim, Surabaya, Maktabah Dahlan, tth. 340-342

Muhammad Husain al-Thabatha'i, Al-Mizan fi Tafsir al-Qur'an, Juz VIII, Beirut: Mu assah al-'A'lami lil Mathu'at, tth

M. Quraish Shihab, Tafsir al-Misbah, Jilid V, Jakarta: Lintera Hati, 2006

Muhammad al-Ghazali, Sounding Alm Against Evangelists, Kairo: Sahwa Publishing House, 1991

TB. Sumarna, Dialog, Kritik, Identitas Agama, Yogyakarta: Dian Interfide, 2002 